\title{
Living in perpetual war but dreaming at perpetual peace
}

\author{
Michael Orzeaţă \\ Department of Communication, Public Relations and Journalism, Apollonia University, Iaşi, Romania
}

Email address:

morzeata@yahoo.com

\section{To cite this article:}

Michael Orzeaţă. Living in Perpetual War but Dreaming at Perpetual Peace. International Journal of Literature and Arts. Special Issue: Discourses of Militarization and Identity: Literature of Conflict. Vol. 2, No. 6-1, 2014, pp. 8-14. doi: 10.11648/j.ijla.s.2014020601.12

\begin{abstract}
The world is the arena of permanent confrontation among individuals and communities. They are pushed toward confrontation by the human beings inner nature and by their contradictory interests. Permanent struggle for money, social position, influence, resources, and territories has different forms of manifestation, from a banal quarrel to fight for survival within the natural jungle as well as to urban jungle and armed conflict. Perpetual peace we dream at is more and more a utopian objective unless we could accept that "Wars no longer begin or end, they are assumed to be the natural continuous state of things".
\end{abstract}

Keywords: Confrontations, Perpetual War, Urban Jungle, Human's Nature, Cruel Leaders

\section{Introduction}

In the year 1990, when the entire world was hoping to end the Cold War, Iraqi leader Saddam Hussein decided to invade Kuwait emirate, which he considered to be part of the historical Ottoman province of Iraq. His decision led to First Gulf War (1991), which was the second ,legitimate war" in the world history. 1 Almost in the same time with the events from the Middle East, the hidden hate between peoples of former Socialist Federative Republic of Yugoslavia erupted in Europe. Between 1991 and 1995, the Former Federative Republics of Yugoslavia fought against each other until the US and other NATO countries decided to intervene for imposing peace. The official dissolution of The United Socialist Soviet Republics (USSR) in 1991 was preceded and followed by a chain of armed conflicts among former federative republics (Armenia and Azerbaijan in 1988 as well as between 1990 to 1992) and between different communities

1 I called it "legitimate" because the United Nations Security Council (UNSC) approved the use of force against Iraq in order to free Kuwait Emirate. The decision has been made in accordance with the UN Chart. I also called it the second "legitimate" war because the first decision of using force by the UNSC was taken on 27th of June 1950, when the North-Korean armed forces invaded South Korean Republic. The decision was possible because the Soviet Union representative in the UNSC was voluntarily withdrawn by the Moscow leader as a form of protest against the world organization refusal to accept Communist China to be part of the UN (more details about this decision could be found in the article UN approves armed force to repel North Korea, published at http://www.history.com/this-day-in-history/un-approves-armed-force-to-repel-nor th-korea, accessed on 10/12/2014). from the newly independent states (Moldova against Transdnestria 1990-1992, South Ossetia and Abkhazia Georgian provinces against Tbilisi regime for being independent states 1990-1992 and 2008, Chechnya against Moscow regime for regaining its independence).

The old confrontation between the Israeli and the Palestinians erupted several times raising concern that the confrontations may extend because the entire Muslim world were supporting their co-religionists against the Jewish people. South-East Asia paid its blood tribute during new confrontations between Muslim and Hindu populations of Kashmir as well as during terrorist attacks from other federative states of the Indian Federation. African continent did not escape from the waves of armed struggles that were storming the world. Sub-Saharan states, Sudan, and North African states were caught in civil wars that were influenced by the direct military interventions from neighboring and Western states.

\section{The World We Live in is the Arena of Permanent Confrontation}

Since the beginning of mankind the human beings used to confront each other, both at individual and community level. The seeds of confrontation exist in each person and it is caused by the people's desire to impose their will on their fellow men. There are many factors that influence forms of confrontation manifesting itself. The most important ones originate within 
the human's inner nature and the second one is the way community people live in influences them. I mean, the character as well as the level of education of each person urges $\mathrm{him} / \mathrm{her}$ to be part of the ongoing confrontations, to initiate or to avoid them.

Every domain of human activity contains different forms of confrontation. Usually we call those confrontations debates, competitions, disputes or conflicts of interests. They exist in sport, scientific, and artistic domains as professional contests, but also in politics, economy, social (as contests for getting jobs or some higher and better paid positions within the organizations), and last but not least, in the military domain as arms race in peacetime as well as fighting combats in war, etc.

Normally, any kind of competition has to be conducted correctly. It means that competitors have to follow rules all of them being known and accepted. As far as we know some participants strive to win the competitions they take by all means. Having this goal in mind they use subversive methods to change and alter the results in a way to favor them. Following the ,rule" of "The reason of the strongest is always the best,"2 (Berg 191) winners are forgiven almost everything, and losers supports the consequences because "Woe to the vanquished!"3 (Berg 341) The blackmail, bribe, deception, violence, threat, constraint, treachery, lies (Volkoff 29), and manipulation of consciousness (Mucchielli 191-193) are among the methods used by those who want to win every kind of competition (confrontation), no matter the cost. The vainglorious and paranoid people, the ones touched by the frenzy of power will always consider a personal insult any kind of failure. They will try to initiate revenge on those people who put them in the shade (Ambrose 28-39). Having all from the above said, no wonder why people will always consider their partners in every type of contest, competition or race as rivals (adversaries). Furthermore, we should not have any illusion about the future of mankind. It is less probable for the confrontation to disappear from the social life. We, the people, seem to be, as the Roman poet Plautus stated more than 2,000 years ago that "Man is a wolf to his fellow man." (Berg 153) Unfortunately, it is hard to say that there have been essential behavioral changes for most of our fellow men. Comparing the people's behavior in Ancient times with modern people way of conduct to each other, it is hard to find big differences between them. Let's recall situations in which some rulers decreed death sentences because the "culprits" did not belong to their ethnic group (Davison 19) or they were their opponents in wars. The Huns leader Genghis Han was famous for killing tens of thousands of enemies, piling their bodies up. (Davison 90) Modern tyrants named Mussolini, Hitler, Stalin, Mao, Pol Pot, Idi Amin, Mobutu, etc. or the employees of "private armies" like Blackwater - that shot innocent civilians (Scahill 30-33) - or Triple Canopy - that practiced the "cult of crime," (Făinaru 40) were as famous as Middle Age's cruel leaders. The difference between modern and medieval tyrants

\footnotetext{
${ }^{2}$ «La raison de plus fort est toujours la meilleure», in French, in original.

${ }^{3}$ Vae victis, in Latin, in original.
}

may lie in the number of the dead people. It is alarming that nowadays "there are still people who [....] pretend to be friends but they are actually rivals, and they want to destroy each other to take other's money and influence." (Martin 13-14)

Taking the individual level of confrontations, one may discover them under the form of the fight for survival in the jungle, the Albanian Kanun, the Italian vendetta, or the struggle to preserve the workplace. Nowadays, the urban jungle may seem similar to the tropical ones. The only difference seems to be the landscape, because the modern world cities oblige their inhabitants to fight for survival every day. Stanley Bing wrote that the most perilous battle ,takes place in the real world, neither on the battlefield nor on the rugby or golf field, but in one with the toughest trenches: the workplace. It is a world where those who do not kick each other's feet, cheat, gobble - and who do not do it with a certain style and grace, I add - remain at the table to pay the bill, while winners go to the next trendy club." (Bing 14)

Throughout mankind's history, people have fought for food, for survival and for a better life that is why I say that life itself is an endless struggle. If one re-evaluates the situation, he/she may find out that: people ,fight" (compete, confront) for a better paid job; sportsmen "fight" not only within boxing matches, but also for trophies; journalists, artists, and other people belonging to other social categories "fight" for titles and prizes; states, communities and organizations "fight" for power, resources, for territories, (Frunzeti 16) for greater influence in the international arena, etc. Thus, we have to fight for whatever we desire or intend to do against nature as well as our fellow men. We have to admit that people, both individuals and communities, are in a permanent confrontation.

Competitions end with losers and winners. Their results leave traces impossible to be erased within the competitors' consciousness. More often losers develop a sense of injustice and they use violent means to take revenge on the winners but also on those who delivered the verdict. This is the one of the ways antisocial deeds (offences) or even terrorist activities occur. If such behavior takes place between individuals or small groups of people, it becomes the subject of a legal action and is called felony. If similar behavior occurs between states, it may also trigger armed violence, namely war, as it is usually called.

Too many times competition changes into rivalry and confrontation, because everybody wants to impose its will and interests on others. Rational and well educated people use to assess the causes of confrontation and the chances and the necessary means to achieve their goals first. Unless the other part forces them to enter into a violent confrontation, they accept to negotiate a solution to end the dispute. What a pity that more and more people act preponderantly under the feelings' impulse and they are seeking only the solutions that accomplish their objectives. Unfortunately, sometimes such kind of people became decision-makers, and they caused armed conflicts because of various reasons such as: the woman they loved was stolen, i.e. as in the Trojan War (Davison 25), because they wanted to increase their possessions or to enlarge their empires, as the Romans, the Persians, the Ottomans, the Habsburgs, the Prussians, the 
Russians, Alexander Macedon, Carol the Great, Peter $1^{\text {st }}$ of Russia, Napoleon etc. did (Loom 74-75); because they pretended not to have enough vital space (as the Nazis did in the Second World War); because they wanted to export communism (as Soviet Union, Che Guevara, and Cuba did), or to prevent the expansion of communism (that's why the Korean War, the Vietnam War, etc. were started). There were also wars to free the states occupied by more powerful aggressors, like the First Gulf War, to stop ethnic cleansing, like the Kosovo War, to destroy terrorism and prevent dictatorial regimes from producing nuclear weapons (as the wars in Afghanistan, in Iraq and military actions against so-called Islamic State of Iraq and Syria -ISIS were), etc.

How could somebody think to ever install the "Perpetual Peace" 4 imagined by Immanuel Kant, and others before him, like the Abbot of Saint-Pierre? Is it possible to decrease confrontations' number, scope and violence? The answer is yes but this objective implies that more and more people become aware of confrontations' danger.

\section{Could We Envision How the Future Warfare Looks Like?}

The concept of future warfare was, is and most probably will be of utmost importance for military experts, political-military analysts as well as political decision-makers. The list of war types is longer or shorter depending on the way of thinking taken by the experts. Some of them want to focus on the common features of wars that were already ended trough a peace treaty. The others want to get into detailed features of wars. Until now the states and the world itself experienced classical, unconventional, prolonged, limited, global, cyber, economic, psychological, electronic, information, hybrid, total wars and so on. The list cannot be limited to those types. As a matter of fact, I think that there is no agreement in concepts regarding war rating. Nobody can even pretend that he/she has all the data within this domain. For instance, the electronic, psychological, information, prolonged wars are considered independent type of wars by some experts, while others think they are part of the modern and total war.

Having these said I do think that we need to know the history and evolution of strategies for waging wars in order to have a base for a good prediction regarding the future of this type of violent confrontation called war. Experts from various think-thanks and thinking schools have been expressed opinions, although there is no guarantee they will be confirmed. As everybody knows, prognoses are probabilistic functions depending on many random variables. That is why prognoses cannot be easily estimated. All the variables I am referring to are influenced by many factors that cannot be totally grasped or even taken into consideration as potential participants in the development of events. Referring to

${ }^{4}$ I. Kant, Perpetual Peace, apud H. S. Reiss (editor), Kant's Political Writings, Cambridge: Cambridge University Press, 1977, and W. B. Gallie, Philosophers of Peace and War, Cambridge, Cambridge University Press, 1978. prognoses, George Friedman, a well-known author and keen analyst in the political-military domain, stated: "I do not have any crystal ball [...] things that appear to be permanent and prevalent at any given moment in history can change with stunning speed." (Friedman 9-12) Referring to the same subject of prognoses, another notorious author, George Maior, the Director of the Romanian Intelligence Service, considers that "Forecast analysis in a medium and long term perspective is always a very ambitious, yet very difficult and risky project. Firstly, its testing in relation to the effective developments in real life is quasi-impossible to be achieved, besides the validity and logic of the argumentation and intellectual construction derived from the analysis and the type of information the analysis is grounded in." (Maior 11)

The aforementioned types of approach may seem pessimistic, but I consider them pertinent and useful. Also I think that each individual, as inhabitant of this world, has to be well-informed about all the aspects that may influence his/her life. This is the way that can help the people from every corner of the world to be less vulnerable to manipulation. Correct and trustworthy information can more successfully help people resist the attempts to be influenced to support the objectives/desires of certain interest groups. I would say that our world is more and less "overwhelmed" with information launched through million of newspapers, tens of thousands of television and radio stations, tens of millions of blogs and websites on the Internet.5 In order to safe "navigate" through these avalanches of information provided by so many sources we need to be helped with timely and accurately information as well as a kind of algorithm to select useful from useless and harmful information. In this respect, I would like to mention the initiative of an American printing house, namely Greenhaven Press Inc. It publishes some books in the collection called "Opposing Viewpoints," which "present stimulating debates that can be used to enhance and teach skills [...] to compare different viewpoints [...] to attain the higher-level thinking skills [...] so essential in a culture of diverse and contradictory opinions." (Markley \& McCuan 9)

There are many situations when communities are involved in tense relations, which may escalate till the use of military force, if they are not well managed. That is why the information related to all these situations are useful not only for decision-makers, if it is timely and well argued to be credible, but also for the people who are not concerned with national security or who are not so well-educated. My point here is that ordinary people have to get out from the "maneuver mass" which is the role reserved them for too many politicians. I will prove my previous assumption with the case of the second Iraq war in 2003. The war was ignited following the presumption the Baghdad regime of Saddam Hussein would have continued to work covertly on obtaining nuclear weapons. The assumption was followed by a very well operation of manipulating American citizens as well as an

\footnotetext{
5 "The Rise of the Digital Information Age", The Washington Post. February 11, 2011.

http://www.washingtonpost.com/wp-dyn/content/graphic/2011/02/11/GR2011021 100614.html, accessed on February 3, 2014.
} 
important part of the population worldwide. 6 The case of the second Gulf war has been for many years and even nowadays is widely debated in the international media, especially post facto, unfortunately. 7

There have been published quite many books related to future wars. One of them was written by the American Trevor N. Dupuy, a former colonel in the U.S. Army. His Future Wars book, published in 1993, is a chain of predictions about the outbreak of potential wars. The author identified ten wars, among them being the India-Pakistan War, the Israel-Arab War, a new war in Iraq, the Sino-Russian War, the Egypt-Libya War, etc. From all the author's predicted wars, the new Iraq war broke out in 2003, but in a different context than the one imagined by Trevor Dupuy. That means about ten percent of his prognosis became reality. There have been similar predictions to those of Trevor Dupuy, and most likely there may be others in the future. Considering the ratio of probability of these kinds of prognoses it is very important to be careful and to protect ourselves against the traps of influencing. It means that people should not take everything for granted. It is recommended to better inform ourselves and to assess the shocking data and statements prior to believe them and to start acting.

Nowadays, the world is one of a permanent change. It is a world of continuous transformation that may surprise those of us who are not well prepared for living in a frame in which events succeed at an ever increasing speed, and the reference systems, its stability and continuity elements are ever scarcer. Are these changes necessary at such a speed? I have my doubts because I suspect that some re-evaluations are fostered by the desire to "come to the fore with something new." Anyhow, the essence of the world tendency of evolution under the dominating influence of information and globalization is the same. In this respect, I think the opinions that have been expressed on the future war will be validated or not by the years to come. In fact, nobody will know for sure what the future war looks like until that kind of war will start. Unfortunately, under these circumstances, the test of time will be more important for historians than for us, as it would have been a 'fait accompli'!

War is a complex social phenomenon that has an important impact not only on those directly involved in the confrontation but also on the noncombatant people and communities from the area of operations and even worldwide. In our time, more than in any other historic period, there is a great interdependency between communities of people all over the

6 M. Isikoff and D. Corn, Hubris: The Inside Story of Spin, Scandal and the Selling of the Iraq War, Crown, 8 September 2006, apud Martin Kettle, Editorial Reviews, The Washington Post, http://www.amazon.com/gp/product/b000jmkr3e/ref=dp_proddesk1 ?ie=UTF8\&n =283155, accessed on February 3, 2014.

7 M. Cohen, Iraq: A War of Aggression. No WMDs, No Connection to Al Qaeda Global research, March, 19, 2013, http://www.globalresearch.ca/iraq-a-war-of-aggression-no-wmds-no-connection-t o-al-qaeda/5327548, accessed on October 18, 2014; see also Morrissey, Ed, WMD in Iraq a rather nuanced issue, Hotair, July 12, 2014, http://hotair.com/archives/2014/07/12/wmd-in-iraq-a-rather-nuanced-issue/, accessed on October 18, 2014. world, under the pressure of globalization. For the most important part of history, including the last century, the war was associated with the use of brutal force. Right now the war cannot longer be perceived only as a confrontation that employs military means. This is a truth that was understood, especially during the latest decades, by experts from many domains not only from the military one. As a consequence of so many books and articles published on this topic, I hope the complex and real nature of war to have become easier to understand for everyone.

The most popular opinions associated with future warfare seem to be the ones related to the pre-emptive war, (Fukuyama 85) the Fourth World War 8 , (Podhoretz 17-54) fourth generation warfare, (Barnett 8) a new Cold War,9 yet with other players, the permanent warfare, (Mureşan 14) and perpetual war.10 In all these concepts, the military force is no longer the leading, or the most important one. Some authors think that, in the future, "the majority of wars will be civil ones." (Hirst 69) The others envision that future wars will be similar the ones from Bosnia-Herzegovina and Kosovo. They argue that the international community will always intervene to put an end to the conflicts between communities. 11 (Kaldor 148)

In my view, the world will face only one type of warfare the total and continuous (perpetual) one - which humanity has always waged against it. The total and perpetual (continuous) warfare I am referring to is far different from the total war strategy, which was adopted during the Cold War period by some neutral states in Europe. That kind of war had as core element the use of military force to defend country against any aggressor. Romania also adopted a similar war strategy, between 1968 and 1989, called the "entire people's war." The Romania's political leadership decision was influenced by the events from Czechoslovakia in 1968. In that year, the member states of the Warsaw Pact - except Romania - quelled the "Springtime of Prague." (Ianakiev 118-121) That event proved the validity of our forefathers' wisdom. They used to pray to God in order to protect them against their friends thinking that they could protect themselves against their enemies.

8 See also Ch. Krauthammer, In Defense of Democratic Realism, National Interest, no. 77, Washington, 2004.

9 E. Lucas, The New Cold War: Putin's Russia and the Threat to the West, Palgrave McMillan, 2009, New York, USA, http://www.amazon.com/the-new-cold-war-putins/dp/02302614345\#reader-02306 14345, accessed on August 20, 2014; see also Horn, Steve, US-Russia „New Cold War": The Battle for Pipelines and Natural Gas, Global Research August 20, 2013, http://www.globalresearch.ca/us-russia-new-cold-war-the-battle-for-pipelines-and -natural-gas/5346344, accessed on February 20, 2014; see also Applebaum, Ann, China and Russia bring back Cold War tactics, The Washington Post.com December 26, 2013, http://www.washingtonpost.com/opinions/ann-applebaum-china-and-russia-bringback-cold-war-tactics/2013/12/25, accessed on August 20, 2014.

10 J. Shafer, War without end: The U.S. may still be fighting in Syria in 2024, 29134, 2044..., Reuters, September 24, 2014, http://blogs.reuters.com/jackshafer/2014/09/24/war-without-end-the-u-s-may-still -be-fighting-in-syria-in-2024-2034-2044/, accessed on October 17, 2014.

11 M. Ignatieff, Virtual War - Kosovo and Beyond, London: Chotto and Windus, 2000 . 
As I said earlier, many experts launched the concepts that they consider to be new types of war. I am convinced that what is considered to be the future war is, in fact, a continuous transformation (adaptation) of its forms of manifestation from what it was revealed by historians and experts in the field for the past to the conditions that has to be currently met. Adaptability is conceived and implemented in the human mind that always finds new ways to surprise. Surprise has been the main cause of victories in any type of competition and confrontation. I would say that there are not enough reasons to believe that the role of surprise will diminish, at least in the foreseen future. All the times, the area and the strategy of confrontation have always been expanded, through adding new components like non-military domains. By doing this, each competitor has wanted to win by escalating the stages of competition up to the armed confrontation. In other words, I am convinced that warfare has been and will continue to be multidimensional and continuous (perpetual) because, as Tom Toles said, "Wars no longer begin or end, they are assumed to be the natural continuous state of things." 12

The features of warfare are given by factors that influence it. For instance, the multidimensional nature of warfare evolves from the areas of confrontation in which it operates: political, diplomatic, economic, financial, information, technological, psychological, cultural, and military, etc. All these components participate in the confrontation depending on the situation outlined by the objectives set by the political and military decision-makers, the ratio of forces between confronting parties and its evolution perspectives (i.e., through increasing or decreasing the number and quality of own forces as well as of number and military power of allies and supporters and so on), the level of regional and global security, the attitude and the measures taken by countries located in the neighborhood area of operations and by the regional and world security organizations, etc.

The continuous (permanent) character of warfare is given by the permanent competition (confrontation) between individuals, communities (states, alliances, religious, ethnic, professional and other types of entities), between individuals and communities, etc., to better support or impose interests on multiple domains: power, influence, and territories. and resources, be they human, material and financial.

Competition, called by the majority of experts in international relations "games," (Schelling 3-21) is preponderantly conducted "covertly," namely without being declared, through the participation of non-military components - political-diplomatic, 13 (Shulsky 129) economic, information and psychological ones - but it may

12 Toles, Tom, "Friday Rant: Perpetual War edition". The Washington Post, September 26 2014 ,

http://www.washingtonpost.com/news/opinions/wp/2014/09/26/friday-rant-perpet ual-war-edition/, accessed on October 17, 2014.

13 "Influencing the strategies, events or circumstances in other countries is the essence of the foreign policy [...]. The aim of covert actions is to influence the actions of some foreign governments [...] These actions may be aimed at the government of a particular country, the population in general or a certain segment of the population." also get to the so-called "hot phase", namely the one in which military force is used. As a rule, confrontation using weapons signifies the impossibility of the parties to reach an agreement amiably. In other words, as Michael Mandelbaum said, the war is an error into the political judgment, 14 because it never really accomplished its declared objectives and, more than that, it generated a lot of dead people, damages, sufferings and chaos.

I hope not to be so shocking or confusing for almost anyone to hear that we are at war, without perceiving any important difference between the moments before this article was published and the one following them. The situation is quite widespread, not only in the U.S. 15 "Decreeing" the continuous (perpetual) warfare as a modus vivendi refers not only to the current and next period of time we live in, but also to the previous one. The idea of perpetual war will contribute to turning upside down perceptions, images, knowledge, about the world we have lived and will continue to live in.

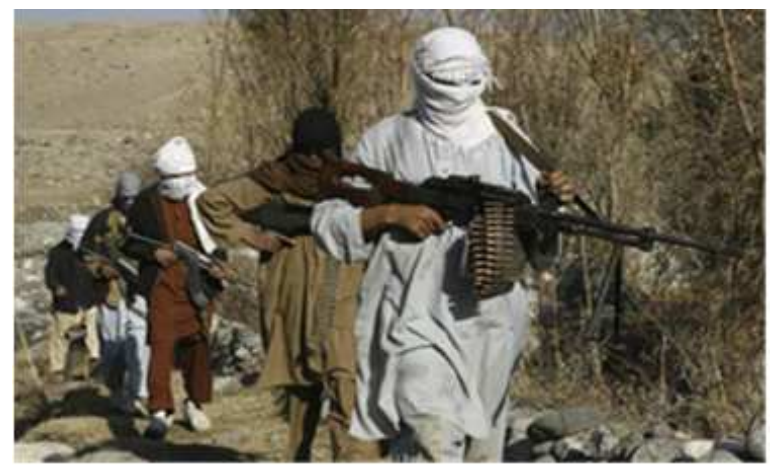

Figure 1. Terrorists in Afghanistan.

Source: Ghosh, Palash, "A cashless economy might reduce organized crime and terrorism: Lipow”, International Business Times, December 22, 2010, http://www.ibtimes.com/cashless-economy-might-reduce-organized-crime-a md-terrorism-lipow-251501, accessed on February 09, 2014.

I suppose that most people have noticed an increase in violence regarding the relations between human beings in almost all the fields of activity, from politics to sports and artistic activities. I also think that most of people who will read these lines may ask themselves some questions, as following: Why daily confrontations should be consider as parts of continuous warfare? How truthful is this concept of perpetual war? What will be the mankind's future? The questions could reflect the desire to discover the truth; it might be also a form of skepticism as well a form of disappointment because we, the people of this planet Earth dream at perpetual peace, and instead of having it we get a perpetual war. It is

14 M. Mandelbaum, "From the Archives: The Failure of Intervention", Foreign Policy, September/October, 1999, http://www.foreignpolicy.com/articles/55396/michael-mandelbaum/from-the-arch ives-the-failure-of-intervention, accessed on June 24, 2014.

15 U. Friedman, "Is peacetime or Wartime in America?" The Atlantic, September 11 , 2014 ,

http://www.theatlantic.com/international/archive/2014/09/obamas-losing-battle-w ith-perpetual-war/380060/, accessed on October 19, 2014 ("Obama is losing his battle with perpetual war"). 
only natural to be so, as all of us have been taught war presupposes armed violence, casualties and important material and spiritual losses. Another possible question could be "What is the solution?"

An answer to this question is that a system of relations between people may be built, at both individual and community levels, in which confrontations should be preponderantly nonviolent. I do believe that it is possible to build a system in which the potential for conflict existing in every human being could find a suppression valve in participating in any kind of nonviolent competition like: sports, art, scientific, professional and so one. In this way, the negative energies may be consumed without causing too much physical and moral damage. The utmost objective, which I consider utopian, would be the disappearance of violent confrontations, while the realistic objective is to bring confrontations at a bearable level!

Reminding our own experience, also the stories that have been told us by our grandparents, parents or other relatives, as well as from written and filmed stories, the conclusion is that life has continued including in wartime. I mean children have been conceived and born, agricultural fields have been sown and crops harvested, economy have been produced commodities alongside with weapons and ammunition, artistic production has been imagined, and people have been died not only from shots and bomb or missile explosions. In other words, the armed conflict is a catastrophe, a great drama for those directly involved in it, as well as for their families, and friends. On the other side, members of the community continue to live, at a different pace, one altered by the events, but... everyone adapts.

I recall that in the $16^{\text {th }}$ century, the French individuals from around royal family invented the interesting formula of "The King is dead, long lives the king." (Bluche 82) This formula has been used up to the funeral of Louis XVIII. In my view, this way of thinking and acting was maybe a little bit cynical. From another point of view, the aforementioned formula expresses, in a concise way, the sequel of royalty, but also of life itself. While some people mourn their dead, the others celebrate births, weddings, etc. Adapted to the topic of the article, "the King is dead, long lives the king" describes, to a great extent, the current condition of humanity, dominated by confrontation: some people die, because of wars, but humanity continues to exist, as life has to take the course.

\section{Conclusions}

Most of the people do not pay enough attention to daily confrontation, especially at an individual level. We all call this type of confrontations stress and we consider it an annoying or a problem-generating factor only when it creates us problems, literally or figuratively. This way of thinking could be explained through certain patterns like considering confrontation only that violent dispute that has tragic consequences for us or our fellow men. Every individual wishes to live a peaceful, satisfied and a happy life. This could be one of the reasons for not paying the proper attention to the endless and almost daily verbal disputes and to gradually transformation of competitions in confrontations for a workplace or a shelter, for gaining a market to the detriment of a competitor, etc.

Sport has increasingly become a business, as well as a fight. Competition on economic markets is so tough that it is called "economic warfare," while at the political level disputes are heading many times towards confrontation (in international arena it is called: ideological warfare, cold war, frozen conflict, relations breakdown, etc. In the internal political environment, competitions became fights. Moreover, former partners that have changed their political formations become adversaries and often enemies, in an attempt to win the votes of the electorate)

Debates on ideas are - almost anytime - providers of "psychological warfare." Therefore, competing interests change into disputes that, in turn, change into non-military conflicts that are amplified and, many times, are growing to the stage of conflicts with military means. Thus, the evil in us accumulates drop by drop until the violence appears, destroying everything, and hardly can we repair the damage afterwards.

\section{References}

[1] I. Berg, Dicţionar de cuvinte, expresii, citate celebre (Dictionary of Words, Expressions, Famous Quotations), Bucharest: Vestala Press, 2004, p. 191.

[2] V. Volkoff, Dezinformarea văzută din est (La Désinformation vue de l'est/Misinformation Seen from the East), Bucharest: Pro Editura and Print Press, 2007, p. 29.

[3] A. Mucchielli, Arta de a influenţa (L'art d'influencer Analyse des techniques de manipulation/Art of Influencing. Analyse of the Techniques for Manipulation), Iaşi: Polirom Press, 2002, pp 191-193.

[4] T. Ambrose, Despoți şi dictatori (The Nature of Despotism. From Caligula to Mugabe, the Making of Tyrants), Bucharest: Litera Press, 2008, pp. 28-39.

[5] M.W. Davison, Unde, când, cum şi de ce s-a întâmplat (When, Where, Why \& How It Happened. The most Dramatic Events and How They Changed the World), Bucharest: Reader's Digest Ltd. Press, 2005, p. 19.

[6] J. Scahill, Blackwater: ascensiunea celei mai puternice armate private din lume (Blackwater: the Ascension of the most Powerful Private Army of the World), Bucharest: Litera International Press, 2007, pp. 30-33.

[7] S. Făinaru, Legea celor puternici (The Law of the Powerful), Bucharest: Litera International Press, 2009, p. 40.

[8] C. Martin, Clubul Bilderberg: stăpânii lumii (The Bilderberg Club: Masters of the World), Bucharest: Litera International Press, 2007, pp. 13-14.

[9] S. Bing, Sun Tzu era un biet mototol. Subjugă-ţi adversarii, ţine-ţi aproape prietenii şi stăpâneşte adevărata artă a războiului (Sun Tzu was a Sissy: Conquer your Enemies, Promote Your Friends, and Wage the Real Art of War), Bucharest: Curtea Veche Publishing, 2009, p. 14. 
[10] T. Frunzeti, and V. Zodian, Lumea în 2009. Enciclopedie politico-militară. (Studii strategice şi de securitate) [The World in 2009, Political and Military Encyclopedia (Strategic and Security Studies)], Bucharest: Armed Forces Technical-Editorial Press, 2009, p. 16.

[11] M.W. Davison, "The Beginning of the Greek Dark Ages", in When, Where, Why \& How It Happened. The most Dramatic Events and How They Changed the World, Bucharest: Reader's Digest Ltd. Press, 2005, p. 25.

[12] H.W. van Loom, Istoria lumii (History of the World), Bucharest: Tai-Pan Ltd. Press, 1993, pp. 74-75, 91-101, 125-130, 257-259, 285-293.

[13] G. Friedman, Următorii 100 de ani. Previziuni pentru secolul XXI (The Next 100 Years. Forecasts for the $21^{\text {st }}$ Century), Bucharest: Litera Press, 2009, pp. 9, 12.

[14] G. Maior, "Foreword", in A.N. Shulsky and G.J. Schmitt, Războiul tăcut. Introducere în universul informațiilor secrete (The Silent Warfare. Understanding the World of Intelligence), Iaşi: Polirom Press, 2008, p. 11.

[15] O. W. Markley and W. R. McCuan, 21 $1^{\text {st }}$ Century Earth, Opposing Viewpoints, San Diego: Greenhaven Press, Inc., 1996, p. 9.

[16] T. N. Dupuy, Future Wars, New York: Warner Books Inc., 1993.

[17] F. Fukuyama, America la răscruce. Democraţia, puterea şi moştenirea neoconservatoare (America at the Crossroads. Democracy, Power and the Neoconservative Heritage), Filipeştii de Târg: Antet XX Press, 2006, p. 85.
[18] N. Podhoretz, "World War IV: How It Started, What It Means, and Why We Have to Win", Commentary 118, no. 2, 2004, pp. $17-54$.

[19] T.P.M. Barnett, Blueprint for Action: A Future Worth Creating, New York: Berkley Books, 2006, p. 8.

[20] M. Mureşan (Gen.) and Ghe. Văduva (Gen. Brigadier, ret.), Războiul viitorului, viitorul războiului (War of the Future, Future of the War), Bucharest: National Defense University Press, 2004, p. 14.

[21] P. Hirst, Război şi putere în secolul XXI. Statul, conflictul militar și sistemul internațional (War and Power in the $21^{\text {st }}$ Century. State, Military Conflict and International System), Filipeştii de Târg: Antet XX Press, 2006, p. 69.

[22] M. Kaldor, New and Old Wars: Organized Violence in the Global Era, Cambridge; Polity Press, 1999, p. 148.

[23] N. Ianakiev, "Several Bulgarian Secret Records from 1968 concerning the Position of Romania toward the Invasion in Czechoslovakia", in On Both Sides of the Iron Curtain, Bucharest: Military Press, 2000, pp. 118-121.

[24] T.C. Schelling, The Strategy of Conflict, Cambridge, MA: Harvard University Press, 1999, pp. 3-21.

[25] A.N. Shulsky and G.J. Schmitt, Războiul tăcut. Introducere în universul informaţiilor secrete (Silent Warfare. Understanding the World of Intelligence), Iaşi: Polirom Press, 2008, p. 129.

[26] F. Bluche, De la Cezar la Churchill (Dictionaire des mots historique. De Cesar a Churchill/Dictionary of Historic Words. From Cesar to Churchill), Bucharest; Humanitas Press, 1995, p. 82. 